Portland State University

PDXScholar

Anthropology Faculty Publications and

Presentations

Anthropology

7-1996

\title{
Wearing a Dead Man's Jacket: State Symbols in Troubled Places
}

Michele Ruth Gamburd

Portland State University, b5mg@pdx.edu

Follow this and additional works at: https://pdxscholar.library.pdx.edu/anth_fac

Part of the Social and Cultural Anthropology Commons Let us know how access to this document benefits you.

\section{Citation Details}

Gamburd, Michele Ruth, "Wearing a Dead Man's Jacket: State Symbols in Troubled Places" (1996). Anthropology Faculty Publications and Presentations. 43.

https://pdxscholar.library.pdx.edu/anth_fac/43

This Post-Print is brought to you for free and open access. It has been accepted for inclusion in Anthropology Faculty Publications and Presentations by an authorized administrator of PDXScholar. Please contact us if we can make this document more accessible: pdxscholar@pdx.edu. 


\section{WEARING A DEAD MAN'S JACKET: STATE SYMBOLS IN TROUBLED PLACES}

Michele Ruth Gamburd

Anthropology Department

Portland State University

P. O. Box 751

Portland, OR 97207-0751

July 1996

\section{ABSTRACT:}

A village rumor concerning the attempted theft of a uniform from the corpse of a Sri Lankan army soldier supplies the subject matter for this paper. In May 1993, soon after the assassination of President Ranasinghe Premadasa, a spectacular local funeral for a Low Country Sinhalese soldier killed in the civil war near Trincomalee provided a space for the display of state symbols, the voicing of patriotic rhetoric, and the exhibition of the precision and discipline of the national army. Military pageantry legitimated the use of force by the government, while the funeral ritual as a whole produced a catharsis of love, grief, and patriotism. However, several days after the funeral, rumors circulated that grave robbers had tried to steal the uniform in order to use it as a disguise while committing crimes locally (as during the period of the recent insurgency), or to sell it to the separatist army in the North. A veiled counter-discourse of illegitimate violence surfaced concerning atrocities committed by the army, by the insurgents, by the separatists, and by private citizens pursuing personal vendettas. These rumors revealed a space for play, parody, betrayal and deception within the official aggregate of military signs. Symbols of state power acquired multiple and ambiguous local meanings, reflecting a continued local consciousness of the disorder and terror of the previous decade of insurrection and covert state violence. This paper examines how structures of nationalism and justifications of violence are reproduced, challenged, and transformed at the village level.

Focusing on a case study of a soldier's funeral and the subsequent desecration of his grave, this paper examines the use and abuse of military symbols against a local background of the legitimate and illegitimate use of force..$_{1}$ In May 1993, soon after the assassination of President Ranasinghe Premadasa, a spectacular local funeral for a Low Country Sinhalese soldier killed in the civil war near Trincomalee provided a space for the display of state symbols, the voicing of patriotic rhetoric, and the exhibition of the precision and discipline of the national 
army. Military pageantry legitimated the use of force by the government, while the funeral ritual as a whole produced a catharsis of love, grief, and patriotism. However, several days after the funeral, rumors circulated that grave robbers had tried to steal the uniform from the corpse in order to use it as a disguise while committing crimes locally (as during the period of the recent insurgency), or to sell it to the separatist army in the North. A veiled counter-discourse of illegitimate violence surfaced concerning atrocities committed by the army, by the insurgents, by the separatists, and by private citizens pursuing personal vendettas. These rumors revealed a space for play, parody, betrayal and deception within the official aggregate of military signs. Symbols of state power acquired multiple and ambiguous local meanings, reflecting a continued local consciousness of the disorder and terror of the previous decade of insurrection and covert state violence.

The incident around which I center this paper occurred in the lowland coastal village I call Kosgahakanda 2 , where I spent eighteen months in 1992-1994. Situated about fifty miles (or two and a half hours by public bus) south of the capital city of Colombo, the village area was home to about one hundred fifty households and about a thousand people. Women worked most frequently as garment factory workers, as school teachers, and as housemaids in the Middle East. Many men in the village made their living working as cinnamon peelers, day laborers, and army soldiers.

Bloody ethnic conflict in Sri Lanka makes the international news on a depressingly regular basis. Sri Lanka has been embroiled in an ethnic civil war for over a decade ${ }_{3}$, with the government army struggling against separatist Tamil militant groups (dominated by the Liberation Tigers of Tamil Ellam, or the LTTE) in the North and East. Sparked by riots in 
Colombo in July 1983, the armed conflict represents the culmination of thirty years of postindependence wrangling over language policy, land, legal codes, and access to University education, among other issues in the ethnic strife. On 1 May 1993 a suicide bomber of alleged LTTE affiliation assassinated the President, Ranasinghe Premadasa. In November 1994 peace talks with the newly elected Sri Lanka Freedom Party (hence SLFP) ${ }_{4}$ government shakily survived the assassination by suicide bomber of a prominent opposition leader.5 In April 1995 the fragile cessation of hostilities broke down, spinning Sri Lanka into yet another round of armed conflict in the North and the East, with the LTTE retaliating against the military capture of the Tamil capital, Jaffna, by detonating a bomb that destroyed much of Colombo's financial district in late January 1996. Efforts toward a federalist devolution of power continue alongside military operations.

In addition to the ongoing civil war in the North and East, Kosgahakanda residents were swept up in the events of two internal insurgencies in the South. The Marxist-nationalist Janatha Vimukthi Peramuna, or People's Liberation Front (hence JVP) staged rebellions against the state, one in 1970-71, the other in 1988-90. The more recent conflagration was concentrated mainly in the deep South, with the violence peaking in early 1989. In easy walking distance of the village, and home of a weekly fair, the town of Urugasmanhandiya provided a great deal of support to the JVP. Although villagers claim few if any people in their strongly-pro-government ${ }_{6}$ village of Kosgahakanda were involved with the JVP, I heard several accounts of a local JVP organizer whose body was burnt on tires at a junction just five minutes' walk away. On nights when the electricity went out, family members in the house where I lived gathered on the front steps to talk. Occasionally, in hushed voices, they spoke about the insurgency, saying that in those days, 
people stopped eating fish, because so many corpses had floated down the rivers to the ocean. They remembered anonymous threats tied to bricks flung at the house, general strikes that virtually shut down the country, masked men with weapons, food shortages, dread, and fear. The United National Party (UNP) government lead by President Premadasa brutally suppressed the JVP insurgency. Government forces freed from the civil war by the presence of the Indian Peace Keeping Force (IPKF) in the North in 1987-1989 made an all-out, no-holdsbarred effort to restore order in the South. In addition to torture and disappearances attributed to the government and to the JVP, private parties pursued personal vendettas under cover of the endemic violence. Estimates vary, but perhaps 60,000 people, mostly young men, died during the insurgency.

\section{Case Study}

Against this background of perennial violence, I relate a series of events that took place in early May 1993. At that time candidates for the Provincial Council Elections were campaigning fiercely for an election scheduled for 17 May 1993.7 Politicians criss-crossed the country, speaking at every opportunity. Ironically, although the Provincial Councils were established in 1987 as part of an effort toward regional devolution of political power, the central government had decided not to hold elections in the North and the East since the fighting there was too fierce.

On 23 April 1993 Lalith Athulathmudali, a prominent opposition leader who broke with Premadasa's ruling UNP party in late August 1991, was assassinated while giving a campaign speech in Colombo. Although the government called in experts from Scotland Yard and 
tentatively held the LTTE accountable for the shooting, angry rumors suggested that the government itself might be responsible. Just over a week later, the President, Ranasinghe Premadasa, was killed in by a suicide bomber of suspected LTTE affiliation while organizing a UNP May Day march on 1 May 1993.

Sandwiched between the nationally publicized funeral of Lalith Athulathmudali and the internationally broadcasted death of President Premadasa, a soldier from the village was killed by a 'Tiger' attack on a six-man guard post near Trincomalee, a large natural harbor in the Northeast. Although many men from Kosgahakanda were employed in the army, until the 30th of April 1993, there had been no fatalities from the immediate area. As signs of mourning, white flags abounded in the village, some for Athulathmudali, some for Nimal, the village man killed by the Tigers, and many (most) for the President.

Despite the Tiger connections with two and perhaps the third of these deaths, people did not speak much about the Tamils in the North. Discussion focused instead on economic issues in the South. While no one said that the war was good, a career in the army had many advantages. The army paid well, especially for dangerous assignments, and in addition to the salary, the pension and death settlements provided generously for the bereaved family. There were few other high-paying jobs available in the local area, even to those with O-level (tenth grade) education. In the dead man's family alone, many men, including a brother, three cousins, two brothers-in-law, and two uncles, currently served in the army.

Following local custom, people from every household in the village went to pay respect to Nimal's body during the three days it lay in the living room of his mother's new, halfconstructed cement house. Flowers, wreaths, oil lamps and plaster elephant tusks surrounded the 
body in its open casket, and a white plastic canopy hung from the ceiling above. Four pieces of flesh-colored tape covered areas of the swollen face. One covered the chin, one covered the forehead, and one covered each ear. Local speculation suggested that the tape marks covered entry and exit wounds of bullets, and that the shots had been administered at close range. rest of the body, clad in a beige khaki uniform, seemed intact.

On the day of the funeral, crowds of friends, relatives, politicians, and neighbors came to Nimal's house. Eleven monks from local temples performed the last rites under a tin roofed shelter in the lawn, and then village notables and visiting politicians took their turns giving speeches to an audience of about two hundred people. While a retired school principal was remarking how Nimal had studied in the local high school and died bravely for his country, several army vans arrived and parked fifty yards down the shaded red dirt path. All the little boys ran off to see the thirty-man honor guard. The soldiers marched in line into the house to pay their last respects to the body.

After the speeches, the family closed the coffin. Six male friends and relatives carried it out the door and down the steps. Because the grave site was just across the path from the house, and since both the family and the army felt some form of a procession was in order, the six casket-bearers took the coffin a hundred yards down the path away from the house and grave, walking on a white cloth thrown under their feet, shaded under a white canopy, preceded by drummers pounding out the tell-tale five-beat death cadence, to the nearest small junction. There they turned the casket over to the military. The soldiers covered the coffin with a national flag and tassels, and laid a hat, belt, and dagger over the lid. They marched back up the path, past the house, to the nearby grave site. Six hatless soldiers carried the casket. 
The soldiers brought the casket under the large decorative marquee arching over the entrance to the land. They marched with the coffin three times around the grave and laid it on two wooden saw-horses resting on a carpet on the ground. An officer announced over a loud speaker Nimal's name and rank, the details of his life-- his birth date, the day he joined the army, the places he had been stationed, and the day he died. The family members stood on the other side of the clearing, amidst a crowd of around three hundred onlookers.

An officer returned their hats to the six soldiers carrying the casket, who marched to the edge of the clearing. Fifteen other soldiers marched into a two-row formation at the side of the grave, and at the command of their leader readied, aimed, and fired their weapons twice in salute. They then marched out of the center of the clearing, and the six casket-bearers returned to the side of the coffin, surrendered their hats, picked up the coffin, and delivered it down into the brick tomb of the grave.

\section{The Discipline of Soldiers}

The government requires discipline from its soldiers. The neat uniforms, the red feathered caps, the shiny shoes, the clear hierarchy, the synchronized movements, the crisp salutes, all spoke of training and obedience, mechanical precision and the fulfillment of orders. In contrast to the weeping relatives, the hysterical mother-in-law and the drunken drinking buddy, the army arrived to bury their own, on time, armed with the definitive dates and facts of Nimal's life and death, to place him in a proper grave with all the fitting rituals and national pageantry. The soldiers stood straight and silent at attention, awaiting the commands of their superiors, while the bereaved friends and relatives hugged and leaned on each other, sat on 
the ground, cried, and shouted angrily. The pain and suffering of friends and family counterpointed the sternness and order of military bearing and demeanor.

Nimal's close relatives came to the funeral out of feeling and duty; many others came out of curiosity, to see the soldiers and watch the performance. Little boys drawn by the romance of uniforms and guns followed every action of the honor guard with bated breath; the ritual indoctrinated a second generation of Sinhala men into the glory of armed service. Shows of discipline such as that at Nimal's funeral legitimate the army's right to bear arms by demonstrating soldiers' obedience to higher orders. The uniformity of dress and the synchrony of movement as each soldier acted in unison, on command, emphasized the collective nature of violence in war; each man seemed to become an interchangeable part of a smoothly-functioning whole. The performance suggested that soldiers have no license to move, let alone kill, of their own initiative, without orders from their superiors, and that the violence they unleash against the enemy is under the full regulation of state authorities. 'Our boys' will do to Tamil youths what the Tigers did to Nimal, hold a gun to a stranger and put a bullet through his body, because they are disciplined, trained, and paid to do so by their country, for the 'good' of their country. Personal anger, grudges and hasty decisions have no place in the controlled violence of war as represented in the funeral ritual.

Although I interviewed none of the honor guard who performed the military rites, and while I have no personal experience with armed service, I speculate that the precision, order, and control of the funeral must have affected the soldiers as strongly as it did their audience. While the funeral service brought about a patriotic catharsis of love, grief and nationalism in the onlookers, it might also have kept at bay the fear and the pathos inherent in the soldier's 
recognition that 'This dead man could be me,' and the correlated question, 'Is the cause worth this sacrifice?' Taking part in the remembrance and respect for a fallen comrade could comfort the soldiers themselves, with the order of the ritual acting as a foil for the chaos of battle, countering the uncertainty and dread of war. The polished shoes, the starched shirts, the crisply ironed pantlegs, all juxtaposed the disintegration and disorganization, the shit and the blood, the terror and the rage of battle.

Death, an intensely powerful transfer point of meaning, provides a prime locus for the challenge and reinforcement of national and religious ideas. Continental philosopher Martin Heidegger (1962) suggests that people carry out their day to day activities without thinking much about death. The ritual of a funeral, and the presence of a corpse, according to Heidegger, bring home the 'ownmost' and certain quality of death for each participant and onlooker at a funeral, shaking their complacency and prompting a thorough reexamination of the principles and priorities imposed by the surrounding culture, which Heidegger refers to as the 'theyself'. Examining the larger social significance of death, Elaine Scarry (1985) argues the at-firstcounterintuitive idea, that while the causes of conflict legitimate death in war, just so the deaths serve to legitimate the conflict. Warring parties engage in contests of injuring and killing soldiers (rather than racing horses or playing chess) precisely because of the power of dead and maimed bodies to sanctify the cause for which they consented to suffer.

Paradoxically, death can spur two opposite reactions. First, death can banish what Heidegger refers to as 'inauthenticity', a mindless self-alienation in the tranquillity of the surrounding culture. For those closely related to Nimal, perhaps the irrevocability of his death brought home the futility of the war in the North. Second, death can serve as a staging ground 
for the indoctrination of large groups of people into the dominant national and religious discourse on the value of war. For others less emotionally tied to the irrevocability of Nimal's death, the rituals seemed rather to laud the causes for which he gave his life. Nimal's funeral provided a context par excellence for the display of a powerful sign (the dead body) and the legitimation of a killing contest (the Sri Lankan ethnic conflict). Death can be seen not only as a catalyst for the escape from the mentality of the masses, but also as an energizing element fueling local and national rhetoric.

Recent anthropological discussions of the nature of resistance challenge the possibility of an autonomous subject agent (Abu-Lughod 1990, Mitchell 1990, O'Hanlon 1988). No mind interacting in the network of socially shared meanings could achieve a self-constituting, selfdetermining consciousness uninfluenced by a dominant discourse. Contrary to Heidegger's claim that death could chase away the stifling influence of the 'they-self', contemporary writers argue that no one can completely escape contextualization in the hegemony of cultural constructs. At the same time, no ideology holds complete and total sway over its subjects, and different ideas compete for attention. Dominance evolves in dialogue with opposition; where you find power, you also find resistance (Foucault 1978). However, resistance is rarely singleminded and unambiguous; in situations of oppression ethnographers often encounter both accommodation and defiance, consent and coercion, acceptance and denial. Studies of agency and resistance strive to document and explain this sort of contradictory subjectivity (MacLeod 1992). The manifold, cross-cutting flows of power and knowledge in the events surrounding Nimal's funeral reveal a multiplicity of overlapping, contradictory voices each interpreting circumstances differently. 
The chief monk, the retired school master and the politician who spoke at the funeral all stressed that Nimal died serving his country, protecting the Sinhala homeland, and preserving a safe haven for the Buddhist religion. Traditional religious and secular practices bracketed the event, with the local monks and educated elites reinforcing the army's ritual messages of nationalism. The Sri Lankan state and the Buddhist religion have long existed in symbiosis, with historical kings and current rulers making significant contributions to the Buddhist Sangha (order of monks). In this context the civil war was portrayed not only as a challenge to the integrity of the Sri Lankan state, but also as a threat to the Buddhist religion, which President Premadasa and other Buddhists were duty-bound to preserve (Kapferer 1988, Tambiah 1992, van der Horst 1995). Nationalism has created a particular variety of Buddhism, and has in turn become a part of the religious practice. Reciprocally, religious myths and legends affect the construction and interpretation of the nation at both the state and local levels.

Structural and individual poverty plays a large role in perpetuating the armed conflict in Sri Lanka. A recent discussion of human rights (Martinez 1996) suggests that economic deprivation can severely constrain individuals' freedom of choice. Good health, education, a decent standard of living, and other material conditions for self-development are central to preserving an individual's 'free' agency and a community's self-reliance, and thus central to the debate on human rights. Similarly, economic considerations enter into an analysis of Nimal's funeral. Village discussions of military service rarely if ever failed to include detailed accounts of military salaries and benefits, as opposed to the high level of local male unemployment. While pitying Nimal's widow, neighbors also speculated on how much money the army had paid for funeral arrangements and compensation.s The poverty of the village made 
military service a logical choice for bright, energetic, talented boys. Once enlisted, soldiers learned to be physically useful and politically obedient participants in the ethnic conflict. The lack of economic opportunities undermined humanitarian sentiments, the Buddhist precept of ahimsa (non-violence), and one element of the eight-fold noble path to the cessation of suffering: right livelihood (not to make a living from any occupation that could bring harm to others, such as trafficking in arms, poisoning creatures, or killing fellow humans). ${ }_{10}$ Sinhala nationalism and Buddhist chauvinism went hand in hand with a stern reality of limited opportunities-- both for the Tamil separatists in the North, and for the men from the South who joined the army. Shortages and the scarcity of other options for development contribute both to social unrest (the rebellion in the North and the insurgency in the South) and to a ready supply of youth willing to serve as soldiers. An elective affinity between the dearth of other economic opportunities, and various myths and legends of state and religion, encouraged 'voluntary' military service and an accompanying justification of violence in nationalistic and religious rhetoric.

Nimal's village funeral echoed in a small way the massive outpouring of grief and the monumental display of state symbols surrounding the funeral on 6 May 1996 of President Premadasa. In Colombo, mile-long lines of mourners waited hours in the hot sun and the pouring rain for a chance to file past the President's closed casket. Patriotic speeches, Buddhist rites, and displays of military discipline reached millions both in person and through the media. State pageantry and religious symbolism in highly emotional circumstances legitimated the preservation of 'the nation' and 'the faith' -- constructs recreated and reinforced by just such ceremonies as Nimal's funeral and Premadasa's funeral. Both the soldier and the President died 
for their country, killed by the Tigers. Villagers in Kosgahakanda experienced both on the local level and on the national level a symmetrical catharsis of love, grief, and patriotism. The isomorphism between village and country reveals the practices by which nation and religion are reproduced at the state and local levels.

IV. Desecration of the grave

Late at night on 10 May 1993, five days after his funeral, Nimal's burial site was disturbed. The wreaths and flower decorations were thrown down from the large decorative arch, the white painted pots on the posts around the grave were broken, and the plastic of the white canopy that had been carried over his coffin and now lay over his grave was punctured. Bystanders suggested that someone had been pounding with a metal pole on the cement slab over the grave, pointed to the sandy soil and said that it had been disturbed. Fortuitously, the coffin had been solidly sealed in a brick tomb.

Rumor circulated in the village that the person who desecrated the grave had been trying to steal the army uniform worn by the corpse. With the uniform, the grave robber could perform robberies and thefts in the guise of a military man. People cited their experience during the JVP insurgency, when private feuds and vendettas were conducted by rogues in official dress, as proof that such things happened. (I was told that the army, finally recognizing the extent of the problem, had assured citizens during the height of the conflict that no legitimate army personnel would ever come calling after dark.) If the grave robber did not use the uniform himself, he could sell it for a good price up North, to the LTTE or other interested parties.

Village opinion immediately selected a likely culprit. Nimal's family and the brothers of 
the family next door were disputing the ownership of the land on which Nimal was

buried. Nimal's widow had ordered his grave dug on the twenty perch (eighth of an acre) piece of land in which she had purchased shares with money she had earned working as a housemaid in the Middle East. Burying a body on a piece of land stakes an indisputable claim to possession, but at the same time the presence of a grave renders the area unfit for habitation; a number of villagers commented that in her grief, Nimal's widow was ruining a perfectly good housing plot. ${ }_{11}$ By burying a dead brother about two hundred yards from Nimal's gravesite, the neighbors had laid similar claim to a nearby plot of land six weeks prior to Nimal's funeral. Since the neighbor claiming direct ownership of the land was serving a jail term at the time of Nimal's funeral, a third brother of his had been pursuing the land dispute.

Many local people, including my research assistant, held this neighbor responsible for desecrating the grave. Even his mother admitted that her son had been drinking the night the grave was disturbed. Nimal's brother reported the incident to the police and the army, and claimed that an army representative had instructed his group to find the suspect, beat him up, and then return to the army camp themselves for a week or two, until the situation cooled down. Four or five young men on bicycles searched far and wide for days for any sign of the suspect. The ritual of a military funeral clothed the land dispute and vendetta in national significance, transforming what would otherwise have remained a complicated village altercation into simple treason against the country. At the same time, the local focus allowed an outlet for anger through definitive action; Nimal's brother and friends concentrated their energy on locating and attacking their neighbor, a much more tangible target than the faceless LTTE. Perhaps anticipating the village's righteous wrath, the accused grave-desecrater was nowhere to be 
found.

\section{Writ large, writ small}

Just as interesting and important as the local politics surrounding the land dispute and family feud, was the rumor that circulated attributing the motivation for the desecration of the grave to the attempt to steal Nimal's uniform. The swiftness with which the rumor spread, and the alacrity with which it was accepted as plausible, reflected a continued local consciousness of the disorder and terror of the previous decade of insurrection and covert state violence.

Rituals of nationalism create a dense network of symbols around the military. Military dress, decorum, hierarchy and terminology all index one fraternity with a single style. Respect for the man in uniform shades into respect for the uniform. Just as Nimal's cap, belt and dagger on his coffin came to represent him, so the Sri Lankan lion-flag on the coffin became a metonym for the nation. The symbolism inherent in Nimal's funeral echoed that of President Premadasa's funeral, melding soldier with nation, President with state, in a superabundance of nationalist fervor.

Symbols, however, have a life of their own, and meanings are never unitary. Most communication takes place through metaphors, whose specific present interpretations depend on current context to pull a rabbit of specific meaning from the hat of inherently polysemic potentialities (Derrida 1977, 1978). Symbols taken out of one context and placed in another cause a brief disorientation; this moment of shock or realization is the essence of humor and the challenger of habit (Peirce 1955). Both the comedian and the con artist rely on the strength of assumptions to carry the audience and the dupe on unaware into the 'punch line' or the 'sting', 
when the second meaning of utterance and action suddenly comes to light, "Illuminating hidden historical landscapes in a flash"(Coronil and Skurski, 1991:290). Rumor in this case suggests that the dead man's jacket as multivocal symbol would lend an aura of official sanction in the hypothetical context of illegitimate action-- be it private thuggery or covert state violence. Such use of a uniform would at once depend on and undermine its authority. The continuous use of symbols in multiple contexts results in a dynamic variety of meanings, creating the opportunity for play and parody, betrayal and deception (Bakhtin 1981).

History is a story about the past recreated in the present with an eye to shaping the future. Such a narrative is as much about what a nation remembers together as it is about what they imagine, and what they forget in unison (Anderson 1991). The events left out of the authoritative picture of the past remain repressed in a nation's subconscious as discounted, subjugated knowledge, 'forgotten', only to resurface at unexpected times, in unexpected places. Although not usually talked of or even brought to mind, this knowledge haunts the margins of consciousness, dogging the hegemonic discourse.

At the time of the funerals of the soldier and the President, local village rumors challenged the automatic respect for military uniforms, the unhesitating trust in the army, and the mechanical confidence in the state. Two associations accompanied Nimal's death and the events following his funeral: the official image of national pride and patriotism on the one hand and rumors and memories of illegitimate uses of force on the other. Similarly, the President's death also spurred two separate reactions in the village: grief, stunned disbelief, and sorrow on the one hand and a muted sense that he who had ordered and condoned the torture and disappearances associated with the suppression of the JVP insurgency had died an appropriately violent 
death. Similarly, Athulathmudali's death generated two separate plot lines: the first that the Tigers had targeted him, since he had been the Minister of Defense before leaving the ruling party; the second that the President had eliminated a dangerous rival. These mingled, contradictory stories revealed how afterimages and aftereffects of insurgency, counter insurgency, and civil war possessed the population, "Challeng[ing] not just the official version of events but the government's capacity to construct its own image"(Coronil and Skurski 1991: 309). The fractured images showed just how deeply the context of current, chronic violence had ruptured any simple local trust in authority.

As an authorless story, rumor is less likely to incriminate those who merely retell or 'animate' (Goffman 1981) it than those who author their own treasonous thoughts; nevertheless, its agentless awareness expresses a subaltern, resisting discourse with a different set of 'facts' at its disposal. Anthropologists who theorize about violence (Das 1990, Feldman 1994, Taussig 1987) speak of the importance of witnessing and memory in countering violence and terror. Rumor acts as a deputy witness, a communal subjectivity, an autonomous imagination circulating a story at once outrageous and plausible. Rumor's orgy of colorful, excited talk about possible presents and futures reflects a bleak knowledge of an all-too-real, all-too-solemn past. The exaggeration and distortion inherent in most rumors define the genre in juxtaposition to the stern discipline of the authoritative discourse. Believing neither point of view entirely, villagers could and did voice either discourse sincerely as the context warranted.

The rumor of the attempted theft of Nimal's uniform lapped against the edifice sanctified by the state, revealing thinly veiled local knowledge of illicit state and civil violence. Like a wake in a river channel reverberating off the sea-walls long after the boat has passed, the rumor 
was an sudden swell surging up unexpectedly from a local land dispute and a family feud. The rumor surrounding the dead man's jacket was but one small sign of deeper currents of chaos in state symbols in Sri Lanka. Bearing witness to all that has been consciously suppressed or subconsciously forgotten, the rumor revealed the incomplete mastery of the state's authoritative discourse, and highlighted the places where authorized knowledge did no longer or not yet coincide with lived experience.

The rumor surrounding Nimal's uniform revealed the ambiguity and contradiction in the 'official' aggregate of military symbols. State symbols in troubled places revealed not only the national pride, but also the deep but thinly veiled awareness of atrocities recently performed and experienced. Poverty and previous patterns of experience made stealing the clothing from a corpse an obvious interpretation of events to those in the village, for whom the 1989-90 events of the JVP insurgency lay only just below the surface of consciousness. Rumor, as self-control without conscious agency, catalyzed a process of deconstructing hegemony (Daniel 1993). In juxtaposition to the display of military discipline, a counter-discourse of crimes committed by the army, the JVP, and the LTTE-- and by others under the mantle of their name and uniform -- at once borrowed from and challenged the honor and respect ordinarily called up by the military symbols. Examining the microprocesses of nationalism and national ritual at the village level shows how symbols of state power acquired multiple and ambiguous local meanings, reflecting a local history of disorder and terror. Future proposals to resolve the ethnic conflict in Sri Lanka must take into consideration these subconscious habits of thought now deeply ingrained in the population.

\section{BIBLIOGRAPHY}


Abeyesekera, Charles and Newton Gunasinghe, eds. Facets of Ethnicity in Sri Lanka. Colombo, Sri Lanka: Social Scientists Association. 1987.

----- Ethnicity and Social Change in Sri Lanka. Colombo, Sri Lanka: Social Scientists Association. 1985.

Abu-Lughod, Lila. "The Romance of Resistance: Tracing Transformations of Power through Bedouin Women" American Ethnologist 17,1 (1990):41-55.

Anderson, Benedict. Imagined Communities. London: Verso. 1991.

Bakhtin. The Dialogic Imagination. Michael Holquists, ed. Austin: University of Texas Press. 1981 [1935].

Bastin, S. "Political Economy of Ethnic Violence in Sri Lanka: The July 1983 Riots" Mirrors of Violence: Communities, Riots and Survivors in South Asia. Veena Das, ed. Delhi: Oxford University Press. 1990. pp. 286 -304.

Coronil, Fernando and Julie Skurski. "Dismembering and remembering the Nation: The Semantics of Political Violence in Venezuela." Comparative Studies of Society and History 33,2 (1991). pp. 288-337.

Daniel, E. Valentine. "Tea Talk: Measures of Labor in the Discourse of Sri Lanka's Estate Tamils." Comparative Studies of Society and History 35,3 (1993): 568-600.

Das, Veena, ed. Mirrors of Violence: Communities, Riots and Survivors in South Asia. Delhi: Oxford University Press. 1990.

Derrida, Jacques. "Signature, Event, Context" Glyph 1(1977): 172-97. ----- "Ellipsis" Writing and Difference, A. Bass (trans.) Chicago: University of Chicago Press. 1978.

Feldman, Allen. "Ethnographic States of Emergency." MS. 1994.

Foucault, M. Discipline and Punish. Trans. Alan Sheridan. New York: Vintage. 1979.

----. The History of Sexuality. Vol. I. New York: Vintage. 1978.

Gamburd, Michele. 1993 "A Village View of the Provincial Council Elections, May 1993," The Thatched Patio Vol. 6 Number 5 (1993). Colombo, Sri Lanka: International Centre for Ethnic Studies. pp. 32-47.

Goffman, Erving. Forms of Talk. Philadelphia: University of Pennsylvania Press. 1981. 
Heidegger, Martin. Being and Time. J. Macquarrie \& E. Robinson trans. Oxford: Basil Blackwell. 1962.

Kapferer, Bruce. Legends of People, Myths of State: Violence, Intolerance, and Political Culture in Sri Lanka and Australia. Washington: Smithsonian Institution Press. 1988.

MacLeod, Arlene Elowe. "Hegemonic Relations and Gender Resistance: The New Veiling as Accommodating Protest in Cairo." Signs: The Journal of Women in Culture and Society 17,3 (1992): 533-557.

Martinez, Samuel. "Indifference within Indignation: Anthropology, Human Rights, and the Haitian Bracero". American Anthropologist 98,1 (1996) pp. 17-25.

Mitchell, Timothy "Everyday Metaphors of Power." Theory and Society 19,5 (1990): 545-577.

Obeyesekere, Gananath. A Meditation on Conscience. Colombo: Social Scientists' Association of Sri Lanka. 1988.

O'Hanlon, Rosalind. "Recovering the Subject: Subaltern Studies and Histories of Resistance in Colonial South Asia" Modern Asian Studies 22, 1 (1988) pp. 189-224.

Peirce, Charles S. Philosophical Writings of Peirce. Ed. Justus Buchler. New York: Dover Publications Inc. 1955.

Rahula, Sri Walpola. What the Buddha Taught. London: Gordon Fraser. 1967.

Ram, Mohan, Sri Lanka: The Fractured Island. Penguin. 1989.

Scarry, Elaine. The Body in Pain: The Making and Unmaking of the World. Oxford University Press. 1985.

Spencer, Jonathan, ed. Sri Lanka: History and the Roots of Conflict. New York: Routledge. 1990.

Tambiah, S. J. Buddhism Betrayed? Religion, Politics, and Violence in Sri Lanka. Chicago: University of Chicago Press. 1992.

----- Sri Lanka: Ethnic Fratricide and the Dismantling of

Democracy. Chicago: University of Chicago Press. 1986.

Taussig, Michael. Shamanism, Colonialism, and the Wild Man. Chicago: The University of Chicago Press. 1987.

van der Horst, Josine. 'Who is He, What is He Doing': Religious Rhetoric and Performances in Sri Lanka during R. Premadasa's Presidency (1989 - 1993). Sri Lanka Studies in the Humanities and the Social Sciences, Vol. 2. Amsterdam: VU University Press. 1995 
${ }_{1}$ This paper was initially prepared for a panel entitled "Recreating Community: Ritual and Violence in Sri Lanka's shattered World" and presented at the 1995 Annual Meetings of the American Anthropological Society, held in Washington D.C. I would like to thank my fellow panelists (Dennis McGilvray, Patricia Lawrence, and Mark Whitaker) and our discussants Margaret Trawick and David Little, as well as my colleague Sharon Carstens for their helpful suggestions in revising this piece. Many of the insights herein are theirs; the flaws are my own. This research was made possible in part by National Science Foundation Dissertation Research Award grant number DBS 9207143.

${ }_{2}$ To preserve the privacy of the people involved, I have used pseudonyms for both the village and its inhabitants. Dates and details of the stories have been accurately represented to the best of my ability. ${ }_{3}$ Although the lines of cleavage between the major groups involved in the ethnic conflict only solidified in the past half a century, groups trace justifications for their solidarity much further into the past. The current categorizations are largely based on language groups, with religious and historical subdivisions. The majority population (74.0 percent) speaks Sinhala and predominates in the south and west of the island. The dominant minority, the Tamils (18.2 percent) is segmented into the Ceylon Tamils (12.6 percent), who hail from the north and east and trace their arrival on the island to before the days of colonization, and the so-called Indian or Plantation Tamils (5.6 percent), who are descendants of coolie laborers brought from South India by the British to work on tea and coffee plantations in the mountainous central section of the island. In the eastern provinces reside a Tamil-speaking group of Muslims (7.4 percent) who regard the prospect of becoming a religious minority within a prospective Hindu state of Tamil Eelam with ambivalence at best. The source of these figures is the 1981 Census, as reported in Tambiah (1986:

4). Due to the civil war and the insurrection, the 1991 census was not performed.

For more information on the ethnic struggle, see Tambiah (1986), Spencer (1990), Ram (1989), Obeyesekere (1988), Kapferer (1988), Das (1990), Abeyesekera and Gunasinghe (1985, 1987).

${ }_{4}$ The SLFP and the United National Party (UNP) are traditional rivals in Sri Lankan politics. The SLFP is a socialist/ leftist party, while the UNP holds free-market/ conservative policies.

${ }_{5}$ I refer here to Gamani Dissanayake.

${ }_{6}$ The free-market oriented United National Party (UNP) held power in Sri Lanka from 1977 until 1994, when a coalition government lead by the socialist Sri Lanka Freedom Party (SLFP) came to power. Kosgahakanda residents have a history of voting for the UNP, and remained largely loyal to the state during the insurgency.

7 See Gamburd (1993).

${ }_{8}$ Based on my scanty knowledge gathered from detective novels and television shows, very little would have remained of Nimal's skull had shots been administered to the head, especially at close range. The rumor's emphasis on the brutal face-to-face nature of Nimal's last encounter, however, merits analysis in and of itself.

${ }_{9}$ In 1993 approximately Sri Lankan Rs. 20,000 (US\$ 500 at 1993 exchange rates, or 5 months' salary) were given for the funeral, while approximately Rs. 100,000 (US\$ 2,500) were given as a death settlement. In addition, the soldier's widow received a generous monthly pension.

${ }_{10}$ See Rahula (1967).

${ }_{11}$ Much to everyone's surprise, she later constructed a house on that same property. 